Journal of Economics and Behavioral Studies

Vol. 5, No. 6, pp. 346-355, June 2013 (ISSN: 2220-6140)

\title{
Relationship between Fiscal Deficit and Public Debt in Nigeria: an Error Correction Approach
}

\author{
*Benjamin Ayodele Folorunso, Olanipekun Emmanuel Falade \\ Obafemi Awolowo University Ile-Ife, Osun State, Nigeria \\ *bfolorun@oauife.edu.ng3
}

\begin{abstract}
The paper examined the nexus between fiscal deficit and public debt in Nigeria. Public debt was disaggregated into domestic and external debt with a view to analyzing the causal relationship and relative effect of both categories of debt on fiscal deficit. Time series data were collected from Statistical Bulletins published by the Central Bank of Nigeria from 1970 to 2011. Except for inflation rate that was I(0), the unit root test results revealed stationarity of fiscal balance, public debt and its components, income, exchange rate and rate of interest series at their first difference; they are I(1) series. Pair-wise Granger causality results support bi-directional relationship between fiscal balance and public debt as well as its domestic component while causality run only from external debt to fiscal deficit. Johansen cointegration results also confirmed the existence of cointegrating relationships at 5 per cent level of significance. In addition, error correction estimates revealed that fiscal balance had significant positive relationship with debt in Nigeria in both the short and long run. The results showed that 1 per cent increase in public debt resulted in an increase of 1.85 per cent in fiscal deficit. In addition, 1 per cent increase in fiscal deficit resulted into 0.08 per cent increase in public debt. The paper further confirmed that domestic debt has greater impact on fiscal deficit than external debt. The paper concluded that the Nigerian government should consider appropriate mix of domestic debt and external debt as a mean of financing budget deficit.
\end{abstract}

Keywords: Fiscal deficit financing, public debt, public finance, causal relationship, time series analysis

\section{Introduction}

Much of the macroeconomic instability that beset many developing countries, including Nigeria, in the 1980s, which include debt crisis, high rate of inflation, low investment and poor growth performance, has been attributed to the persistent of fiscal deficit (Lad, 1984; Okunrounmu, 1993; Chimobi and Igwe, 2010). Several attempts at regaining macroeconomic stability through fiscal adjustment achieved uneven success in developing countries, thus raising questions about the macroeconomic consequences of fiscal deficit. Much of the evidence in the literature has strong support for the view that fiscal deficit prior caused debt crisis in many developing countries. However, the effects of fiscal deficits on debt depend strongly on the financing methods adopted and the country's macroeconomic conditions (Ogunmuyiwa, 2008 and 2011). Thus, the objective of government deficit financing is to mobilize financial resources, taking into account elements of cost and risk, as well as macroeconomic implications of various sources of financing. The persistence of fiscal deficit in Nigeria confronts government with the decision of choosing among minting of currency, increase taxes, incur domestic or external debt or combination of any of these means in financing the deficit. It may, however, be counter-productive if appropriate mix of financing is not ensured. Indeed, a wrong choice or mix among these sources might run counter-productive to the macroeconomic objectives of maintaining price stability, employment generation, high level of investment, accelerated development and satisfactory foreign reserve (Beaugrand et al, 2002). For instance, minting of currency may be inflationary while increase in tax rate may produce high rate of interest, thus, retarding capital formation and economic growth (Anyanwu, 1998). Also, the choice of public debt (either domestic or external) as source of financing deficit may generate larger deficit as allocation has to be made for servicing the debt in the subsequent fiscal year thus resulting in perpetual deficit as in the case with the Nigeria economy (Adedotun, 1997). This is an indication that public debt may be a cause of fiscal deficit in the country.

Controversial results have been reported in the literature on the nexus between fiscal deficit and public debt. Some authors opine that the level of public debt required depends strongly on the magnitude of the fiscal 
deficit. If this view is valid, the implication is that the direction of causation runs from fiscal deficit to public debt (Kruger, 1987; Noll, 2004; Michael, 2011). It has also been observed in the literature that the level of debt is prior cause of fiscal deficit in developing countries (Klein, 1994 and Ariyo, 1993) while some authors found no strict causal relationship actually exists between the variables (Ogunmuyiwa, 2011). Therefore, the issue of the direction of causation between fiscal deficit and public debt is yet to be resolved in the literature. In addition, the component of debt that has causal relationship and their relative impact on fiscal deficit has also not been addressed. Indeed, domestic debt may lead to credit squeeze through higher interest rates thereby crowding out private investment and consumption (Onwioduokit, 1999) which may eventually lead to further deficit. External debt may also lead to a current account deficit, appreciation of the real exchange rate, balance of payments crisis and higher external debt (Easterly and Schmidt-Hebbel, 1993 and 2003) which may also result into further fiscal deficit. In Nigeria, fiscal deficit has been rising over the years, between 1980 and 2010. As evident in Figure 1, fiscal deficit as percentage of GDP raised from 4.0 per cent in 1980 to 4.5 per cent in 1985, 8.3 per cent in 1990, 8.9 per cent in 1999 which was in most cases above the 3.0 per cent international bench mark. The proportion, however, declined steadily to 2.3 per cent in 2000, 1.1 per cent in 2005 and later rose to 3.8 per cent in 2010. It was during 1995-1996 period that fiscal surpluses were recorded while the percentage of fiscal deficit to GDP was below 1.0 per cent during 2006 to 2008 which could be attributed to debt forgiveness granted the country in 2005 thus reducing the debt servicing burden. Evidence has shown that upward trend of fiscal deficit reported for the sample period was as a result of the volatile revenue base which combines with increasing expenditure profile of government, thus making the incidence of fiscal deficits inevitable, mismanagement of available resources, corruption, social and political crises, creation of more states and local governments, (Egwaikhide, 1991; Chimobi and Igwe, 2010).

Evidence also shows that the deficit was largely financed through external debt as the country relied heavily on foreign financing from official bilateral creditors and multilateral organizations, and less on domestic commercial borrowing as a result of less developed domestic capital market. Prior to 2005 when debt forgiveness was granted to the country, Nigeria's external indebtedness rose from US $\$ 28$ million to over US $\$ 35$ billion, while domestic debt fell from US $\$ 18$ billion to US $\$ 10$ billion during the same period. As shown in Figure 1, external debt as a percentage of the GDP which was 3.8 per cent in 1980 rose sporadically to 25.5 per cent in 1985 and later jumped to the highest record of 111.6 per cent in 1990. The proportion later declined rapidly to 37.1 per cent in 1995 , increased again to 67.6 per cent in 2000 , declined gradually to 18.5 per cent in 2005, and further declined to 2.3 per cent in 2010. The downward trend of external debt witnessed in recent time can be ascribed to the debt cancellation granted to the country in 2005. Domestic debt as percentage of GDP, on the other hand, increased steadily 16.6 per cent in 1980 to 41.2 per cent in 1985 and later fell to 31.4 per cent in 1990 . The proportion reached its highest record of 45.3 per cent in 1994 and since this period the trend of domestic debt has been falling where it recorded 19.6 per cent in 2000, 10.5 per cent in 2005 and rose again to 15.5 per cent in 2010. Many reasons have been adduced for the accumulation of unsustainable levels of external debt in developing countries including Nigeria during the 1980-90 periods. These include, worsening world economic environment, inappropriate domestic policies and poor debt management (Brooks et al, 1998) which led to the classification of these countries as heavily indebted poor countries and were therefore eligible for exceptional debt relief under the Highly Indebted Poor Countries (HIPC) initiative. As at 2005, Nigeria had experienced difficulties in servicing her debt due to relatively undeveloped non-oil private sector, fiscal management difficulties and widespread poverty. This led to the accumulation of substantial domestic and external financing arrears and repeated restructuring of external debt.

Given that the issue of relationship between public debt and fiscal deficit is yet to be resolved in the literature, it is therefore, pertinent to examine the nexus between the two variables. In addition, there is dearth of evidence on the causal relationship between each of the components of public debt and fiscal deficit. This is important in order to suggest appropriate mix of domestic and external debt in financing fiscal deficit in the overall macroeconomic context. The focus of the paper, therefore, is to re-examine the causal relationship between fiscal deficit and public debt as well as its components using Nigeria's data. The main objective of the paper is to determine the empirical relationship between fiscal deficit and public debt using longer sample size. The paper also examines the relative effect of domestic and external debt on fiscal deficit in Nigeria. The rest of the paper is organized as follows: Section II focuses on the review of relevant literature on the causes of fiscal deficit and public debts and macroeconomic consequences of sources of financing fiscal deficit while 
section III presents model specifications and analytical techniques. Section IV presents the discussion of main results and their implications while section $V$ concludes the paper.

Figure 1: Domestic and External Debt and Fiscal Deficit as a Percentage of GDP in Nigeria: 1980-2010

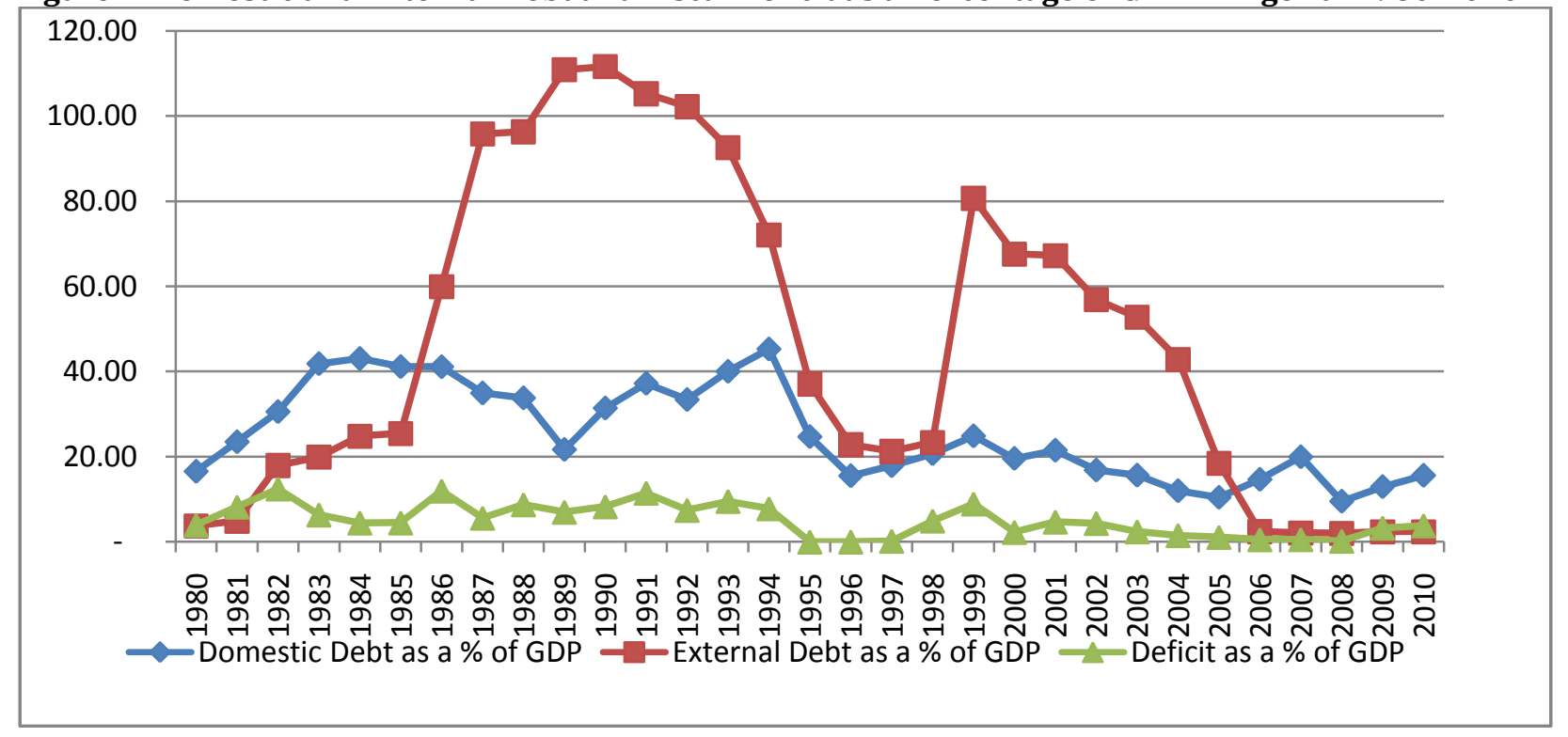

\section{Literature Review}

Debt and monetary financing remain the sources of fiscal deficit financing that have been identified in the literature. While minting of currency and increase in taxes constitute monetary financing, domestic and external borrowing constitute debt financing. The controversy in the literature, however, remains whether or not sources of financing fiscal deficits have macroeconomic implications in an economy. The view of authors on monetary financing is convergent whereas, that of debt financing is divergent. For instance, Easterly and Schmidt-Hebbel (1993) found strong evidence that, over the medium term, monetary rather than debt financing of fiscal deficits leads to higher inflation. In addition, Ariyo and Raheem (1993) highlighted the process in which the financing of huge deficit through ways and means advanced by the Central Bank of Nigeria negatively affected the private sector. However, Keynes (1936) proposed that the appropriate mix of financing fiscal deficit is the adoption of compensatory fiscal policy to manage the economy during the periods of low economic activity. He, argued for increased public expenditure and for it to have the desired effect, it should not be borne out of taxes. Keynes then advocated for debt-financed public expenditure or deficit financing. In addition, Lad (1984) opined that the major cause for a buildup of debt by many third world countries was the need of financing rising public expenditures and the associated fiscal deficit. Summer (1986) argued that the distinction between domestic and external debt is necessary when examining the macroeconomic impact of fiscal deficit financing. In addition, de-Fontenay, Milesi-Ferretti and Pill (1995) opined that external financing could induce greater fiscal and monetary discipline. Boariu and Bilan (2007) also argued that public debt, as all other loans, is costly because government pays interest to their creditors as a price for using the temporary available resources. As a result of its characteristics, public debt can involve several undesired effects. The paper found that debt financing leads to the accumulation of public debt and to the increase in interest payments, which determines an increase in the budgetary expenses that states have to cover. The paper, however found that public debt does not lead to the unjustified increase of the amount of financial signs which are in circulation and it does not generally have an inflationary character. As a consequence, it is usually accepted as a source to finance budget deficits in contemporary society.

The above-reviewed literature indicates that debt source of fiscal deficit financing, whether external or internal, has macroeconomic consequences. Indeed, Gray (1996) and Gray and Woo (2000) affirmed that external financing is not a panacea for governments in developing countries though they further argued that the choice of debt financing must bear in mind other economic policy components, including fiscal policy, 
monetary policy, exchange rate policy and trade policy. Beaugrand, Loko and Mlachila (2002), however, showed that highly concessional external debt is usually a superior choice to domestic debt in terms of financial costs and risks, even in the face of probable devaluation. The causal relationship between public debt as well as its components and fiscal deficit has not been adequately addressed in the literature. Indeed, the relationship between both components of public debt and fiscal deficit is yet to be resolved. For instance, Fischer and Easterly (1990) opined that the relation between monetary financing and budget deficit is neither direct nor linear, especially in the short run. The paper revealed that government borrows to cover a growing deficit indicating that deficit prior cause debt. Some recent studies have examined the determinants of fiscal deficit while few others have focused on the determinants of public debt in high and low income countries. For instance, World Bank (2005) found that changes in public debt-to-GDP ratios broken down into components were attributable to primary fiscal deficits, real GDP growth, real interest rates, the capital gain/loss on foreign currency denominated debt as result of exchange rate changes and fiscal costs associated with contingent liabilities such as bank bailouts. Bandiera (2008) also examined the determinants of public debt dynamics in low income countries (LICs) over the period 1990-2003. The paper found that debt dynamics in LICs are influenced not only by macroeconomic variables but also by the composition of debt and the provision of debt relief over time. In addition, debt dynamics show a high degree of heterogeneity across low income countries which underscore the importance of country-specific factors. The paper concluded that the fiscal stance, structure of the economy, exchange rate systems, composition and structure of the debt and debt management policies are the determinants of public debt.

Sinha et al. (2011) examined those factors that influence the public debt in middle and high income group countries using panel regression and found GDP growth rate as the most important determinant of debt situation for both groups. The paper also confirmed that government expenditure, education expenditure and current account balance impact significant influence on the debt situation for both groups while foreign direct investment and inflation have no impact on debt among high income group countries but they are found to be of more relevance when determining debt situation of middle income group countries. Few studies on the relationship between fiscal deficit and public debt in Nigeria remain controversial. For instance, Ikhide (1995) found that it does not make so much difference whether the deficit is financed by external or domestic borrowing. Okunrounmu (1993), however, attributed the growth in the stock of domestic debt profile to the need to provide financial support for the budgetary gaps of the federal government. Ojo and Okurounmu (1992) also found that increasing levels of fiscal deficit as well as the mode of financing the deficit had resulted in macroeconomic instability and frequent rise in debt had adverse effect on monetary base and money supply. In addition, Michael (2011) found that fiscal deficit determines the size of external debt in Nigeria. The implication of these findings is that fiscal action of the government proxied by its total expenditure and/or fiscal deficit prior-cause public debt while the opposite causality does not hold in the country. This view may not be valid given the review of literature on the determinants of fiscal deficit in developing countries.

Empirical studies in Nigeria failed to address the causal relationship between fiscal deficit and public debt. Indeed, most of the works have focused on the causal relationship between fiscal deficit and macroeconomic variables such as inflation, private investment, money supply, interest rate and economic growth. For instance, Oladipo and Akinbobola (2011) confirmed that there is a significant causal relationship from budget deficit to inflation while Chimobi and Igwe (2010) revealed that money supply causes budget deficit. The paper also found bi-directional causality between inflation and budget deficit in the country. Ogunmuyiwa (2011), however reported that no causal relationship exist between the two variables. It is evident from the review of literature that there is dearth of studies on the nexus between fiscal deficit and public debt as well as its components. The interest of this paper is, therefore, to address the neglect issue on the nexus between fiscal and public debt as well as its components in Nigeria. This is with a view to providing appropriate mix of domestic and external debt in financing fiscal deficit. The paper is of the view that causal relationship may exist between public debt as a whole as well as its components and fiscal deficit in Nigeria. Therefore, the present study fills this gap. 


\section{Model Specifications and Analytical Techniques}

It is evident from the literature that public debt (DEBT) could be a cause of fiscal deficit, also known as fiscal balance (FBAL) while the opposite causality may also hold. Indeed, bi-directional causality may be valid for both series (see Abrego and Ross, 2001; Sinha et al, 2011). In order to ascertain the direction of causation between both series, the paper specifies Granger causality equations as follows:

$$
\begin{aligned}
& F B A L_{t}=\alpha_{0}+\sum_{i=1}^{k} \alpha_{i} F B A L_{t-i}+\sum_{j=1}^{k} \beta_{j} D E B T_{t-j}+e_{t} \\
& D E B T_{t}=\delta_{0}+\sum_{i=1}^{k} \delta_{i} D E B T_{t-i}+\sum_{j=1}^{k} \gamma_{j} F B A L_{t-j}+\varepsilon_{t} .
\end{aligned}
$$

If $\sum_{i=1}^{k} \beta_{j}=0$ and $\sum_{i=1}^{k} \gamma_{j}=0$, then public debt (DEBT) does not Granger cause fiscal deficit (FBAL) in equation (1) and fiscal deficit (FBAL) does not Granger cause public debt (DEBT) in equation (2). It then follows that fiscal deficits and public debt are independent, otherwise both series could be interpreted as a cause to each other. Public debt was further decomposed into domestic (DDEBT) and external (EDEBT) debt. Causality was then examined between fiscal balance and each component of public debt using equations (1) and (2). The nature of causal relationship was used in the specification of fiscal deficit and public debt models as well as its components. If both series cause each other, then each of them becomes the variable to be explained while the other, with control variables, become explanatory variables. Among the auxiliary variables that have been identified in the literature to influence fiscal deficit (FBAL) and public debt (DEBT) is the nominal income (GDP) and rate of inflation (INF) series as mentioned by Abrego and Ross (2001) and Sinha et al (2011). In addition, Bandiera (2008) found that determinants of debt include the fiscal stance (FBAL), the overall size of the economy (GDP), the currency exchange rate (EXR) and interest rate (INT). Incorporating these auxiliary explanatory variables, the fiscal balance (FBAL) model specified in linear form becomes:

$$
\begin{aligned}
\text { FBAL }_{\mathbf{t}}= & \beta_{\mathbf{0}}+\beta_{1} G D P_{t}+\beta_{2} \text { DEBT }_{\mathbf{t}}+\beta_{3} E X R_{t}+\beta_{4} I N F_{t}+\beta_{5} I N T_{t}+e_{t} \\
& \beta_{\mathbf{1}}<\mathbf{0}, \beta_{2}>\mathbf{0}, \beta_{3}>\mathbf{0}, \beta_{\mathbf{4}}>\mathbf{0}, \beta_{5}>0
\end{aligned}
$$

If fiscal balance Granger caused debt, then debt becomes dependent variables and following Bandiera (2008) and Sinha et al. (2011), equation (3) becomes:

$$
\begin{aligned}
\text { DEBT }_{\mathbf{t}}= & \beta_{\mathbf{0}}+\beta_{\mathbf{1}} G D P_{t}+\beta_{\mathbf{2}} \mathbf{F B A L}_{\mathbf{t}}+\beta_{3} E X R_{t}+\beta_{4} I N F_{t}+\beta_{5} I N T_{t}+\mathbf{e}_{\mathbf{t}} \\
& \beta_{\mathbf{1}}<\mathbf{0}, \beta_{\mathbf{2}}>\mathbf{0}, \beta_{3}>\mathbf{0}, \beta_{\mathbf{4}}>\mathbf{0}, \beta_{\mathbf{5}}>0
\end{aligned}
$$

Where DEBT $=$ naira sum of cumulative domestic debt (DDEBT) and external debt (EDEBT)

FBAL = absolute value of the difference between public revenue and expenditure.

GDP = aggregate nominal income proxied by Gross Domestic Product at current basic prices.

EXR = Naira/US Dollar exchange rate index.

$\mathrm{INF}=$ rate of inflation

INT $=$ domestic rate of interest

$\mathrm{t}=$ time (starting from 1970 to 2011 )

Data for estimating equations (1) to (4) were gathered mainly from Statistical Bulletin of the Central Bank of Nigeria from 1980 to 2010. Series were measured in logarithmic form with the exception of exchange, inflation and interest rates. In order to avoid spurious results, unit root tests were carried out on each series in equations (1) to (4). Both the Augmented Dickey-Fuller (ADF) and Philip-Perron (PP) tests were adopted for the determination of the properties of each series. Long run relationships were then examined through Johansen cointegration techniques which were followed by the estimation of equations (3) and (4) using error correction modeling (ECM) techniques. The results of the unit root tests, cointegration and ECM are reported in section IV.

\section{Presentation and Discussion of Results}

Except for inflation rate, all other series reported in Table 1 has unit root property. Both ADF and PP statistics for these series at level indicate values higher than the 5 per cent critical values except for first differencing. 
Hence, they are I(1) series. The results imply that all series has to be differenced once in our models in order to avoid spurious results. The unit root test result was then use in determining the pair-wise Granger causality between fiscal balance and public debt and the results are presented in Table 2. The pair-wise Granger causality test results reported in Table 2 clearly indicate that there is bi-directional causality between public debt and fiscal balance in Nigeria. Indeed, causality runs from debt to fiscal balance at 5 per cent level of significance while opposite causality, that is fiscal balance to debt, only holds at 10 per cent level of significance. The results, thus, indicate that both series are not insulated from each other which follows that fiscal balance could act as a determinant to the level of public debt while the level of public debt could also influence the fiscal balance in the country. Similarly, bi-directional causality result was confirmed for both domestic debt and fiscal balance at 5 per cent level of significance. However, unidirectional causality was reported between external debt and fiscal balance with causality running from external debt to fiscal balance at 10 per cent level of significance.

Table 1: Unit Root Test Results Using ADF and PP (1970-2011)

\begin{tabular}{llllll}
\hline & Level & & First Difference & $\begin{array}{l}\text { Order } \\
\text { Integration }\end{array}$ \\
\hline Series & ADF & PP & ADF & PP & \\
Log of Total Debt ( ln DEBT) & -2.6059 & -1.3090 & -3.6429 & -4.7441 & I(1) \\
Log of Domestic Debt ( ln DDEBT) & -0.5743 & -0.4400 & -4.6179 & -5.2733 & I(1) \\
Log of External Debt ( ln EDEBT) & -1.7534 & -1.6586 & -3.7154 & -4.8103 & I(1) \\
Log of GDP ( ln GDP) & -0.2005 & -0.2065 & -4.0955 & -5.6852 & I(1) \\
Log of RGDP (ln RGDP) & -2.5057 & -2.6369 & -4.6374 & -5.8899 & I(1) \\
Log of Fiscal Balance (ln FBAL) & -2.6466 & -2.4652 & -5.8148 & -8.5051 & I(1) \\
Exchange rate (EXR) & 0.4116 & 0.4607 & -3.9144 & -5.8818 & I(1) \\
Inflation rate (INF) & -3.8733 & -3.3347 & -6.4119 & -6.6670 & I(0) \\
Interest rate (INT) & -1.7110 & -2.0507 & -7.2524 & -9.0539 & I(1) \\
5\% critical values for the rejection of & -2.9358 & -2.9339 & -2.9378 & -2.9358 & \\
hypothesis of unit root & & & & & \\
\hline
\end{tabular}

Source: Estimates from E-View Econometric Package

Table 2: Pair-wise Granger Causality Test Result for Fiscal Balance and Public Debt

\begin{tabular}{llll}
\hline Null Hypothesis: & Observation & F-Statistic & Probability \\
\hline In DEBT does not Granger Cause ln FBAL & 40 & $3.31183^{* *}$ & 0.04817 \\
ln FBAL does not Granger Cause ln DEBT & & $2.91357^{*}$ & 0.06754 \\
ln EDEBT does not Granger Cause ln FBAL & 40 & $2.98309^{*}$ & 0.06364 \\
ln FBAL does not Granger Cause ln EDEBT & & 0.77126 & 0.47013 \\
In DDEBT does not Granger Cause ln FBAL & 40 & $3.32290^{* *}$ & 0.04772 \\
ln FBAL does not Granger Cause ln DDEBT & & $3.90553^{* *}$ & 0.02944 \\
\hline
\end{tabular}

Source: Estimates from E-View Econometric Package

$*, * *$ and $* * *$ indicate 10,5 and 1 per cent level of significance respectively.

The results of Johansen cointegration reported in Table 3 clearly reveal a significant long-run relationship for fiscal balance models as indicated in models 1 and 2 and public, domestic and external debt presented in model 3, and 5 respectively. Indeed, aggregate income, public debt as well as its components, naira-dollar exchange rate, interest rate and rate of inflation series cointegrated with fiscal balance. Also, fiscal balance, income, exchange rate, interest rate and rate of inflation series cointegrated with debt series as well as its components. The evidence of cointegration was further confirmed by the stationarity of the residual terms (ECM) reported in the last row of each model. Both the ADF and PP tests confirm that residual terms are stationary for models 1 to 5 . The evidence of cointegration conforms to error correction mechanism models where both the short run and long run relationships are examined. The results of parsimonious ECM models are reported in Table 4. 
Table 3: Johansen Cointegration Results

\begin{tabular}{|c|c|c|c|c|c|}
\hline Variable & $\begin{array}{l}\text { Model } 1 \\
\text { LFBAL }\end{array}$ & $\begin{array}{l}\text { Model } 2 \\
\text { LFBAL }\end{array}$ & $\begin{array}{l}\text { Model } 3 \\
\text { LDEBT }\end{array}$ & $\begin{array}{l}\text { Model } 4 \\
\text { LDDEBT }\end{array}$ & $\begin{array}{l}\text { Model } 5 \\
\text { LEDEBT }\end{array}$ \\
\hline Constant & $\begin{array}{c}6.4585 \\
(1.3557)\end{array}$ & $\begin{array}{l}10.0697^{*} \\
(1.9573)\end{array}$ & $\begin{array}{l}-2.3831^{* *} \\
(2.5298)\end{array}$ & $\begin{array}{l}-2.5236^{* * *} \\
(4.1461)\end{array}$ & $\begin{array}{l}-5.1876^{* * *} \\
(3.0622)\end{array}$ \\
\hline LGDP & $\begin{array}{l}-1.6710^{*} \\
(1.9429)\end{array}$ & $\begin{array}{l}-3.1676^{* *} \\
(2.5327)\end{array}$ & $0.9631^{* * *}$ & $\begin{array}{l}1.0205^{* * *} \\
(15.7594)\end{array}$ & $\begin{array}{l}1.0088^{* * *} \\
(5.5971)\end{array}$ \\
\hline LFBAL & & & $\begin{array}{l}0.0812 * * \\
(2.5271)\end{array}$ & $\begin{array}{l}0.0626 * * * \\
(3.0160)\end{array}$ & $\begin{array}{l}0.1002^{*} \\
(1.7341)\end{array}$ \\
\hline LDEBT & $\begin{array}{l}1.8566^{* *} \\
(2.5296)\end{array}$ & & & & \\
\hline LEDEBT & & $\begin{array}{l}0.0171 \\
(0.0325)\end{array}$ & & & \\
\hline LDDEBT & & $\begin{array}{l}3.1935^{* *} \\
(2.3376)\end{array}$ & & & \\
\hline EXR & $\begin{array}{c}0.0407^{*} \\
(1.9509)\end{array}$ & $\begin{array}{l}0.0496^{* *} \\
(2.3354)\end{array}$ & $\begin{array}{l}-0.0095^{* *} \\
(2.1927)\end{array}$ & $\begin{array}{l}-0.0086^{* * *} \\
(3.0789)\end{array}$ & $\begin{array}{l}-0.0162^{* *} \\
(2.0940)\end{array}$ \\
\hline INF & $\begin{array}{l}-0.0253 \\
(0.8246)\end{array}$ & $\begin{array}{l}-0.0227 \\
(0.7538)\end{array}$ & $\begin{array}{l}0.0027 \\
(0.4134)\end{array}$ & $\begin{array}{l}0.0012 \\
(0.2911)\end{array}$ & $\begin{array}{l}0.0031 \\
(0.2652)\end{array}$ \\
\hline INT & $\begin{array}{c}0.0042 \\
(0.0331)\end{array}$ & $\begin{array}{l}0.0817 \\
(0.6618)\end{array}$ & $\begin{array}{l}0.0904^{* * *} \\
(4.1977)\end{array}$ & $\begin{array}{l}0.0241^{*} \\
(1.7301)\end{array}$ & $\begin{array}{l}0.1626^{* * *} \\
(4.1994)\end{array}$ \\
\hline R-Square & 0.5802 & 0.6052 & 0.9646 & 0.9822 & 0.9124 \\
\hline F-Statistics & $9.9511^{* * *}$ & $8.9438^{* * *}$ & $196.1783^{* * *}$ & $396.9063^{* * *}$ & $75.0221^{* * *}$ \\
\hline Durbin-Watson Statistic & 1.4572 & 1.5234 & 0.7805 & 0.7862 & 0.6566 \\
\hline ECM: ADF & -4.9392 & -4.902668 & -3.1045 & -3.0536 & -2.9795 \\
\hline PP & -4.6946 & -4.885067 & -3.0086 & -3.2074 & -2.7304 \\
\hline
\end{tabular}

Source: Estimates from E-View Econometric Package. Note that figures in parentheses represent absolute $t$ statistics while *, ** and ${ }^{* * *}$ indicate 10,5 and 1 per cent level of significance. The 1 per cent ADF and PP critical value is -2.6227 and -2.6211 respectively.

The results of estimated ECM parsimonious models are reported in Table 4 with models 1 and 2 focusing on fiscal balance (FBAL) and model 3, 4 and 5 representing total debt (DEBT), domestic debt (DDEBT) and external debt (EDEBT) model respectively. First, the coefficients of past error correction mechanism term [ECM(-1)], which are close to unity, are significantly negative in all models. The error term coefficients conform to a priori expectation in terms of sign and magnitude. The implication of this is that all identified explanatory series in these models 1 and 2, indeed, cointegrated with the fiscal balance series while they also cointegrated with total, domestic and external debt series. This could mean that identified explanatory series namely, domestic debt (DDEBT), external debt (EDEBT), nominal income, exchange rate (EXR) and inflation rate (INF) series have long run relationship with fiscal balance. Similar position holds for debt series as well as its components. All models exhibit high F-statistic and satisfactory coefficient of determination $\left(\mathrm{R}^{2}\right)$ with evidence of no first order autocorrelation as indicated in DW statistics.

Table 4: ECM Parsimonious Results for Fiscal Balance and Debt Models in Nigeria

\begin{tabular}{llllll}
\hline Variable & $\begin{array}{l}\text { Model 1 } \\
\text { LFBAL }\end{array}$ & $\begin{array}{l}\text { Model 2 } \\
\text { LFBAL }\end{array}$ & $\begin{array}{l}\text { Model 3 } \\
\text { LDEBT }\end{array}$ & $\begin{array}{l}\text { Model 4 } \\
\text { LDDEBT }\end{array}$ & $\begin{array}{l}\text { Model 5 } \\
\text { LEDEBT }\end{array}$ \\
\hline Constant & 0.7442 & 0.6314 & 0.0551 & 0.0679 & 0.0129 \\
& $(0.8829)$ & $(0.6680)$ & $\begin{array}{l}(0.9669) \\
0.0163^{*}\end{array}$ & $(1.5311)$ & $(0.1695)$ \\
$\Delta$ LFBAL & & & & \\
& & & $0.0211^{* *}$ & $0.0218^{* * *}$ \\
$\Delta$ LFBAL(-1) & & $(2.3954)$ & $(3.1033)$ \\
$\Delta$ LGDP & $-10.7646^{* * *}$ & $-9.4354^{* * *}$ & & & \\
$\Delta$ LGDP(-1) & $(5.1738)$ & $(4.6512)$ & & &
\end{tabular}




\begin{tabular}{|c|c|c|c|c|c|}
\hline & (3.1545) & (2.9639) & (1.3279) & & \\
\hline \multirow[t]{2}{*}{$\Delta$ LDEBT } & $3.8798^{* *}$ & & & & \\
\hline & $(2.1326)$ & & & & \\
\hline \multirow[t]{2}{*}{$\Delta$ LDEBT(-1) } & $-3.0975^{*}$ & & & & \\
\hline & $(1.7682)$ & & & & \\
\hline \multirow[t]{2}{*}{$\triangle$ LEDEBT } & & $2.1692^{* *}$ & & & \\
\hline & & (2.6322) & & & \\
\hline \multirow[t]{2}{*}{$\triangle \operatorname{LEDEBT}(-1)$} & & $-2.0251^{* * *}$ & & & $0.8692^{* * *}$ \\
\hline & & (2.4859) & & & $(4.0201)$ \\
\hline \multirow[t]{2}{*}{$\triangle \mathrm{LDDEBT}$} & & $5.0435^{* *}$ & & & \\
\hline & & (2.2522) & & & \\
\hline \multirow[t]{2}{*}{$\Delta$ LDDEBT(-1) } & & $-4.5729^{* *}$ & & $0.6576^{* * *}$ & \\
\hline & & (2.2545) & & (3.6825) & \\
\hline \multirow[t]{2}{*}{$\Delta \mathrm{EXR}$} & $-0.0772 * *$ & & $0.0080^{* * *}$ & & $0.0131^{* *}$ \\
\hline & (2.0731) & & $(3.4623)$ & & (2.4393) \\
\hline \multirow[t]{2}{*}{$\Delta \operatorname{EXR}(-1)$} & $0.0636^{*}$ & $0.0616^{*}$ & $-0.0100^{* * *}$ & & $-0.0128^{* *}$ \\
\hline & $(1.7221)$ & (1.8348) & (3.5513) & & $(2.0335)$ \\
\hline \multirow[t]{2}{*}{$\Delta \mathrm{INF}(-1)$} & $-0.0424^{*}$ & & & & \\
\hline & $(1.8494)$ & & & & \\
\hline \multirow[t]{2}{*}{$\Delta \mathrm{INT}$} & 0.1059 & & $0.0141^{* *}$ & & $0.0349^{* *}$ \\
\hline & (1.1327) & & (2.1843) & & (2.3348) \\
\hline$\Delta \mathrm{INT}(-1)$ & & & -0.0116 & & \\
\hline \multirow{2}{*}{$\operatorname{ECM}(-1)$} & $-0.9088^{* * *}$ & $-0.9524^{* * *}$ & $-0.9865^{* * *}$ & $-1.0002^{* * *}$ & -0.9895 \\
\hline & $(4.8056)$ & $(4.6739)$ & $(3.6656)$ & $(3.9205)$ & $(3.5202)$ \\
\hline$R^{2}$ & 0.6034 & 0.6203 & 0.7180 & 0.5149 & 0.5777 \\
\hline F-Statistics & $6.9575^{* * *}$ & $6.3301^{* * *}$ & $8.4866^{* * *}$ & 8.5105 & $6.2203^{* * *}$ \\
\hline DW Statistic & 1.8716 & 1.804324 & 1.9552 & 1.8965 & 2.0759 \\
\hline
\end{tabular}

Source: Estimates from E-View Econometric Package. Note that figures in single parentheses represent absolute t-statistics while ${ }^{*},{ }^{* *}$ and ${ }^{* * *}$ indicate 10,5 and 1 per cent level of significance respectively. Symbol $\Delta$ preceding series represents first difference symbol.

The results reported for models 1 to 3 show no evidence of the catch-up term effect except for models 4 and 5 where the existing domestic and external debt, i.e., lagged domestic debt [DDEBT(-1)] and external debt [EDEBT(-1)], are significantly positive at 1 per cent level of significance. The short run effect of debt on fiscal deficit as reported in models 1 and 2 is also mixed. While the current level of debt (DEBT) and its domestic (DDEBT) and external (EDEBT) bear significant positive effects on the level of fiscal balance, the lagged values of debt (DEBT) and its components bear significant negative effects at 5 per cent level of significance. Also, both the current level of fiscal balance (FBAL) and the past level of fiscal balance [FBAL(-1)] possess significant positive influence on the current level of total debt as in model 3 while only its lagged value bear significant positive influence on domestic debt as in model 4 but no influence at all on external debt as inn model 5. The results reported for fiscal balance models 1 and 2 clearly indicate a significant negative effect of current income (GDP) series and a significant positive effect of lagged income [GDP(-1)] series on fiscal balance at 1 per cent level of significance. Hence, low level of current income accounted for high level of fiscal deficit in the country. The results, however, clearly show that the significant positive effect of the current income series (GDP) on fiscal balance as reported in models 1 to 4 at 5 per cent level of significance but portends insignificant positive effect on current total and external debt in country as reported in model 5 and 6 . The insignificant negative influence of lagged level of income [GDP(-1)] is also reported in all models except for model 3.

The implication of this result is that changes in income level matters in the determination of changes in fiscal balance and that increases in nominal income growth encourage higher fiscal deficits being experienced in 
Nigeria. The level of income has no influence at all on the level of debt and its components as reported in models 3,4 and 5. The effect of current exchange rate (EXR) is significantly negative in model 1 while its significant positive effect is recorded for total debt and external debt models 3 and 5 . The lagged value of exchange rate [EXR(-1)] also produce mixed results. It bears a significant positive effect at 10 per cent level of significance in models 1 and 3 and a significant negative effect in models 3 and 5. The results may indicate that exchange rate fluctuations or devaluation worsen fiscal balance and debt situation in the country. The significant negative effect of lagged rate of inflation [INF(-1)] is only noticed in model 1 at 10 per cent level of significance. The result indicates that the level of inflation bears a negative effect on fiscal balance, which does not support the view that high rate of inflation, is responsible for high fiscal deficits in the country. While the lagged rate of interest [INT(-1)] portends an insignificant negative influence in model 3, the current rate of interest (INT) bears a significant positive effect in models 3 and 5 at 5 per cent level of significance with an insignificant effect in model 1 . The result could mean that high domestic interest rate leads to high rate of debt in the country.

\section{Conclusion and Recommendations}

The paper examined the nexus between fiscal deficit and public debt in Nigeria. Public debt was disaggregated into domestic and external debt with a view to analyzing the causal relationship and relative effect of both categories of debt on fiscal deficit. Bi-directional relationship was confirmed between fiscal balance and public debt as well as its domestic component while causality only run from external debt to fiscal balance in the country. Both domestic and external debt portends positive effect on fiscal deficit in Nigeria. The paper revealed that domestic debt has greater impact on fiscal deficit than external debt. Income growth was found as the key factor influencing fiscal deficit in Nigeria both in short and long run. Rate of inflation was also found to have impacted significant negative influence on the fiscal deficit in the short run while the effect of exchange rate was mixed. The paper concluded that high record of public debt in the country is attributable to high level of fiscal deficits experienced in the country while the level of fiscal deficit was also not insulated from the level of public debt. The paper recommended that the Nigerian government should consider appropriate mix of domestic debt and external debt as a mean of financing budget deficit. It is however expected that further studies on this issue will extend the frontier of knowledge by incorporating measures of foreign capital and depth of domestic financial sector indicators as their non-inclusion serves a major limitation of this paper.

\section{References}

Abrego, L. \& Ross, D. C. (2001). Debt Relief under HIPC Initiative: Context and Outlook for Debt Sustainability and Resource Flows. IMF Working Paper 01/144.

Adedotun, P. O. (1997). Nigeria's Fiscal Policy: 1998-2010. American Economic Review, 38(3), 245-264.

Anyanwu, J. C. (1998). Do Large Fiscal Deficits Produce High Interest Rate?: The Case of Nigeria, Ghana and the Gambia, 1987:3 - 1995:4. Central Bank of Nigeria Financial and Economic Review, 36(1), 51-84.

Ariyo, A. (1993). An assessment of the sustainability of Nigeria fiscal deficit: 1970 - 1990. Journal of African Economics, 2(2), 263-282.

Ariyo, A. \& Raheem, M. I. (1993). Deficit Financing and Economic Development: Empirical Perspective from Nigeria. Project report presented to the African Economic Research Consortium. Abidjan, (December)

Bandiera, L. (2008). Public Debt and its Determinants in Low Income Countries: Results from 7 Country Case Studies. World Bank Working Paper Series.

Beaugrand, P., Loko, B. \& Mlachila, M. (2002). The Choice between External and Domestic Debt in Financing Budget Deficit: The Case of Central and West African Countries. IMF Working Paper WP/02/79.

Boariu, A. \& Bilan, I. (2007). Inflationary effects if budget deficit financing in contemporary economies. Analele Stiintifice ale Universitatii Alexandru Ioan Cuza din Iasi, 54 (November), 77-82.

Brooks, R., Cortes, M., Fornasari, F., Ketchekmen, B., Metzgen, Y. A., Powell, R., Rizavi, S., Ross, D. C. \& Ross, K. (1998). External Debt Histories of Ten Low-Income Developing Countries: Lessons from Their Experience. IMF Working Paper No 98/72.

Central Bank of Nigeria. (2011). Central Bank of Nigeria: Statistical Bulletin. 22 (December)

Chimobi, O. P. \& Igwe, O. L. (2010). Budget Deficit, Money Supply, and Inflation in Nigeria. European Journal of Economics, Finance and Administration Sciences, 19, 52-60. 
De Fontenay, P. B., Milesi-Ferretti, G. M. \& Pill, H. (1995). The Role of Foreign Currency Debt in Public Debt Management. IMF Working Paper 95/21.

Easterly, W. \& Schmidt-Hebbel, K. (1993). Fiscal Deficits and Macroeconomic Performance in Developing Countries. World Bank Research Observer, 8(2), 211-237.

Easterly, W. \& Schmidt-Hebbel, K. (2003). The Macroeconomics of Public Sector Deficits: A Synthesis. In William Easterly, Carlos Rodriguez, and Klaus Schmidt- Hebbel, eds., Public Sector Deficits and Macroeconomic Performance. New York: Oxford University Press.

Egwaikhide, F. O. (1991). Determinants of Fiscal Deficits in a Developing Economy: Evidence from Nigerian. Journal of Economic and Social Studies, 33(3), 177-189.

Fischer, S. \& Easterly, W. (1990). The Economic of Government Budget Constraints. World Bank Research Observer, 5, 127-142.

Gray, S. (1996). The Management of Government Debt. Handbook in Central Banking: NO.5, Center for Central Banking Studies, Bank of England, London.

Gray, S. \& David, W. (2000). Reconsidering External Financing of Domestic Budget Deficits: Debunking Some Received Wisdom. IMF Policy Discussion Paper 00/8, Washington, International Monetary Fund.

Ikhide S. I. (1995). Must a Fiscal Deficit Be Inflationary in a Developing Africa country? Journal of Economic Management, 2(1), 20-34.

Keynes, J. M. (1936). The General Theory of Employment, Interest and Money. Cambridge University Press.

Klein, T. M. (1994). External Debt Management: An Introduction. World Bank Technical Paper No. 245, The World Bank, Washington, D.C. (June).

Kruger, A. (1987). Origins of the Developing Countries Debt Crisis, 1970-82. Journal of Development Economics, 27, 165-187.

Lad, D. (1984). Government Deficits, the Real Interest Rate and LDC Debts: On Global Crowding Out. World Bank Discussion Paper No. DRD 104.

Michael S. O. (2011). Does fiscal deficit determine the size of external debt in Nigeria? Journal of Economics and International Finance, 3(10), 580-585.

Noll, F. (2004). The United States Public Debt, 1861 to 1975. EH. Net Encyclopedia, Edited by Robert Whaples.

Ogunmuyiwa, M. S. (2008). Fiscal Deficit-Inflation Nexus in Nigeria. Indian Journal of Economics, 89(II), 353, 167-175.

Ogunmuyiwa, M. S. (2011). Does fiscal deficit determine the size of external debt in Nigeria? Journal of Economics and International Finance, 3(10), 580-585.

Onwioduokit E. A. (1999). Fiscal Deficits and Inflation Dynamics in Nigeria: An Empirical Investigation of Causal Relationships. Central Bank of Nigeria Economic and Financial Review, 37(2), 1-16.

Ojo, M. O. \& Okunrounmu, T. O. (1992). Why Fiscal Policies Matter in African Countries. Central Bank of Nigeria Economic and Financial Review, 30(4), 220-225.

Okunrounmu, T. O. (1993). Fiscal Operations of the Federal Government: Policies and Strategies since 1986. Central Bank of Nigeria Economic and Financial Review, 31(4), 145-161.

Oladipo, S. O. \& Akinbobola, T. 0. (2011). Budget Deficit and Inflation in Nigeria: A Causal Relationship. Journal of Emerging Trends in Economics and Management Sciences, 2(1), 1-8.

Sinha, P., Arora, V. \& Bansal, V. (2011). Determinants of Public Debt for middle income and high income group countries using Panel Data regression. MPRA Paper No. 32079.

Summer, L. (1986). Debt Problems and Macroeconomic Policies. Symposium sponsored by the FED, Kansas City, August.

World Bank. (2005). Public Debt and Its Determinants in Market Access Countries Results from 15 Country Case Studies. World Bank Research Report, (March) 